\title{
Hibernating astronauts—science or fiction?
}

\author{
A. Choukèr ${ }^{1} \cdot$ Jürgen Bereiter-Hahn ${ }^{2} \cdot$ D. Singer ${ }^{3} \cdot$ G. Heldmaier ${ }^{4}$
}

Received: 29 June 2018 / Revised: 29 November 2018 / Accepted: 3 December 2018 / Published online: 19 December 2018

(C) The Author(s) 2018

\begin{abstract}
For long-duration manned space missions to Mars and beyond, reduction of astronaut metabolism by torpor, the metabolic state during hibernation of animals, would be a game changer: Water and food intake could be reduced by up to $75 \%$ and thus reducing payload of the spacecraft. Metabolic rate reduction in natural torpor is linked to profound changes in biochemical processes, i.e., shift from glycolysis to lipolysis and ketone utilization, intensive but reversible alterations in organs like the brain and kidney, and in heart rate control via $\mathrm{Ca}^{2+}$. This state would prevent degenerative processes due to organ disuse and increase resistance against radiation defects. Neuro-endocrine factors have been identified as main targets to induce torpor although the exact mechanisms are not known yet. The widespread occurrence of torpor in mammals and examples of human hypometabolic states support the idea of human torpor and its beneficial applications in medicine and space exploration.
\end{abstract}

Keywords Hibernation $\cdot$ Torpor $\cdot$ Metabolism $\cdot$ Spaceflight

\section{Background}

For thousands of years, humans dream to fly to the stars. Since some hundred years ago, the distances which we have to pass just to reach the moon or any other planet in our solar system became clear. The fascination of space exploration was even stimulated by this knowledge. Mars is a preferred destination for exploration first by robotic inspection yielding basic knowledge followed by human presence for in-depth investigations. Keeping astronauts mentally and physically in good shape on such a journey of about 560-day duration is one of the great challenges in manned space flights. Flying in a small capsule combines confinement with low physical exercise.

Jürgen Bereiter-Hahn

Bereiter-Hahn@bio.uni-frankfurt.de

1 Laboratory "Translational Research Stress and Immunity", Department of Anesthesiology, Hospital of the University of Munich, Marchioninistraße 15, 81377 Munich, Germany

2 Institute for Cell Biology and Neurosciences, Goethe University Frankfurt, Max-von-Lauestrasse 13, 60439 Frankfurt am Main, Germany

3 Division of Neonatology and Pediatric Critical Care Medicine, University Children's Hospital, University Medical Center Hamburg-Eppendorf, Martinistraße 52, 20246 Hamburg, Germany

4 Animal Physiology, Faculty of Biology, Marburg University, Karl-von-Frisch-Straße 8, 35043 Marburg, Germany
This can cause severe mental problems [78], alter metabolism [92], and influence the immune system, as was shown in bed rest studies and investigations on the effects of confinement, e.g., during the MARS500 study, and in Antarctic stations and underwater habitats [78]. Nutrition, waste management, and environment control have to be tackled. Reduction of nutritional requirements and a state of reduced awareness during the time of flight attaining a metabolic state called torpor (torpeo lat. = to be stiff, numb; corresponding to the physiological situation in hibernating animals during hibernation) would be a game changer in solving these problems for space exploration [37].

\section{Torpor versus hypothermia, coma, and sleep}

Torpor is the physiological basis for hibernation. During torpor, many physiological activities are reduced resulting in decrease of metabolism, body temperature, heart rate, and respiration to a fraction of their normal rate $[25,65$, 113]. Many small mammals like bats, mice, or lemurs become torpid for several hours per day (less than $24 \mathrm{~h}$ ) during their circadian resting phase, a behavior which is called daily torpor. Hibernation is a seasonal behavior consisting of series of multiday torpor bouts (i.e., individual torpor bouts greater than $24 \mathrm{~h}$, most often 10-20 days) interrupted by arousals with euthermic periods lasting 1-2 days. Hibernation is found in many rodent species, bats, lemurs, marsupials, hedgehogs, and bears [33, 43]. As an 
exception, black bears do not interrupt hibernation by arousals but hibernate with depressed metabolism at a body temperature $>30^{\circ} \mathrm{C}[106,114]$. A similar observation was made in lemurs hibernating in thin-walled tree holes where body temperature was raised to $30{ }^{\circ} \mathrm{C}$ every day, whereas lemurs in thick-walled trunks hibernated with lower body temperatures and showed repeated arousals like all other hibernators [22]. This suggests that arousals may be linked to the occurrence of very low body temperatures in hibernation.

Although "human hibernation" is often confused with clinical hypothermia, these are completely different states of metabolic reduction: Whereas hypothermia refers to a state of "passive cooling with subsequent reduction in metabolic rate in critical care patients under drug-induced suppression of thermoregulation," torpor reflects a state of "endogenous metabolic reduction with subsequent fast and extensive decrease in body temperature being limited to a minimal level by maintained thermoregulation" [43, $95,96]$. Thus, long-lasting metabolic reduction in humans might not necessarily require forced external cooling, but to elicit a state of endogenous hypometabolism would induce a much more efficient reduction of metabolic rate (MR) than is possible by hypothermia [33].

Coma is a state of loss of consciousness caused either by cerebral trauma (direct or indirect) or neurologic injuries (e.g., stroke), drugs, or severe metabolic disturbances (e.g., diabetic coma, uremic coma). Such a condition is not comparable to torpid states as the MR is only severely affected in the damaged brain areas, while overall a sympathetic predominance is observed proportionally to the "depth" of the coma. It is not related to reduced MR [66].

The relation between torpor and sleep, especially the question if there is a causal relationship between sleep and torpor, remains still an unresolved issue. During interbout arousals of ground squirrels, an extension of slow-wave sleep is observed, which typically follow periods after sleep deprivation. The conclusion of this behavior was that squirrels aroused from torpor to sleep ("Warming up for sleep?"), indicating that a sleep debt has been built up during torpor which has to be compensated by an extended period of slow-wave sleep [20, 107]. Later studies questioned this conclusion because forced suppression of sleep during the euthermic period did not prevent the onset of the next multiday torpor bout [55]. Nevertheless, slow-wave sleep is regularly observed following arousal from multiday torpor bouts in hibernators as well as following arousal from short daily torpor bouts in hamsters and mice [111, 112]. A link between sleep and torpor is further supported by the 24-h rhythm of daily torpor in hamsters, bats, and mice since torpor occurs preferably during the sleeping phase of the 24-h rhythm [7, 47, 54, 77].

\section{Metabolic rate reduction in torpid mammals and how we can predict metabolic rate in humans during torpor}

Torpor is characterized by a reduction of the MR (measured as oxygen consumption), heart rate, or ventilation frequency accompanied by a controlled decrease of body temperature (Fig. 1). In small mammals, body temperature may closely approach ambient temperature but in larger mammals it may be reduced by a few degrees only. In torpor, most body functions are suppressed to a fraction of their normal rate and metabolic pathways become reorganized in a manner specific for each organ, i.e., shift from glycolysis to lipolysis [1, 42]. As a consequence, this shift increased ketone-based supply for the brain and the heart, respectively [2]. Furthermore, mitochondrial respiration is reduced, as well as gene expression, protein synthesis, and protein degradation are largely suppressed $[9,10,26,110,114]$.

Comparative physiological investigations have shown that hibernating mammals exhibit a more or less uniform massspecific MR, amounting to some $0.1 \mathrm{~W} / \mathrm{kg}$. This is true for both small hibernators and denning black bears although the latter exhibit a much smaller decrease in body temperature $[43,106]$. In other words, the "mouse-to-elephant" curve (metabolic size allometry, Kleiber's rule), reflecting the overall decrease in specific basal MR with increasing body mass, seems to be "switched off" during hibernation (Fig. 2). Remarkably, the minimal metabolic rate of hibernators $(0.1 \mathrm{~W} / \mathrm{kg})$ corresponds to the mass-specific basal metabolic rate that is attained by the very largest mammals, such as whales by pure body size, and might thus indicate a common lower limit to metabolic activity among mammals. Given the fact that the mass-specific basal MR of human beings amounts to some $1.0 \mathrm{~W} / \mathrm{kg}$, there is a theoretical $90 \%$ interspace left for MR reduction in humans from a strictly comparative physiological point of view $[90,94]$.

\section{Protective effects of hypometabolism}

Hypometabolism by natural torpor in humans could have a strong impact on medicine in critical situations $[6,12]$. This can apply for instance for transplantation surgery, as hibernators show resilience to kidney injury which can guide for new measures to preserve explanted human kidneys for transplantation and to hereby increase the organ function in the recipient [86]. Moreover, it has been summarized how research in larger mammals may help to understand and hereby prevent unfavorable consequences e.g. of immobilization, e.g., the bear has mitigated those health challenges humans face as well, e.g., muscle wasting and osteoporosis. Both constitute a severe problem in bed-rested or partly immobilized patients [3]. The knowledge derived in the last two decades from 
Fig. 1 Spontaneous entrance into a hibernation bout in a dormouse (Glis glis) at $5^{\circ} \mathrm{C}$ ambient temperature. Entrance is characterized by a rapid and synchronous depression of metabolic rate, ventilation, and heart rate. Body temperature gradually approaches the level of ambient temperature (modified from $[43,100])$

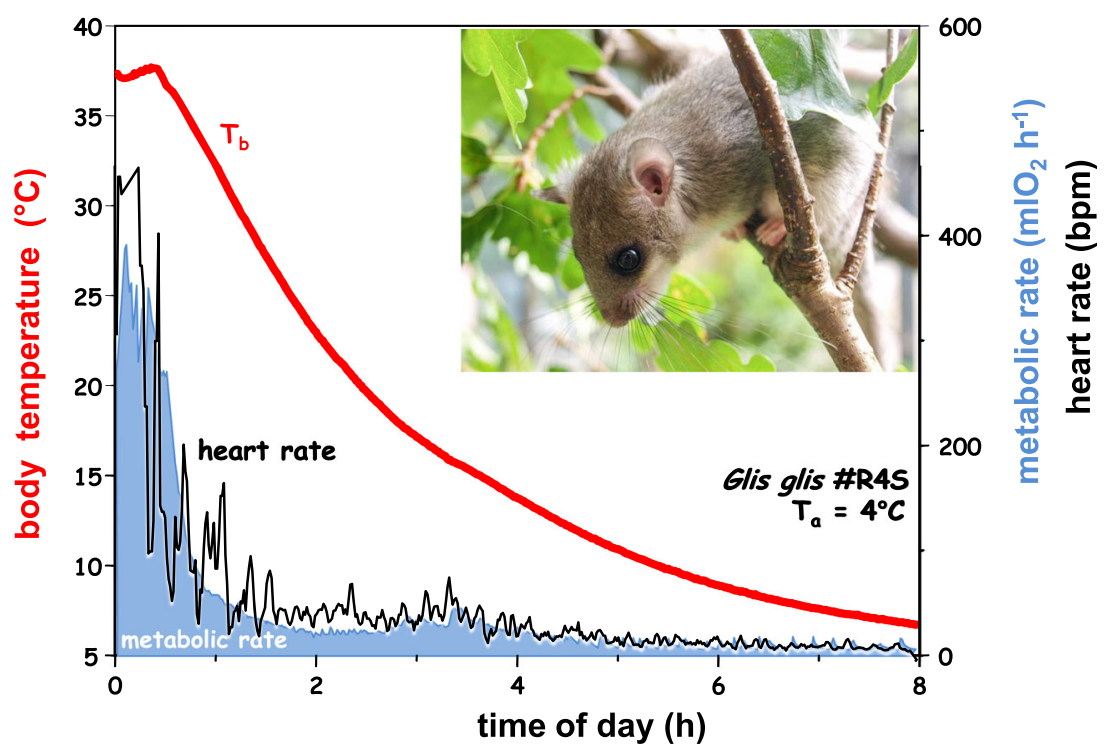

research on hibernators and their hypoxic tolerance [29, 56] will help to understand and hereby modulate regulatory mechanisms to prevent the hypoxemic injuries of the entire body (shock) or of single organs (e.g., brain, liver), thus increasing hypoxia tolerance and avoiding unfavorable conditions of tissue perfusion in the course of (organ) shock and inflammation. Moreover, this knowledge on metabolic regulations in hypoxic tissues will also help to better understand the dynamics of tumor growth, and can shed new light on vulnerable therapeutic windows. In addition, if a tumor could be put into a state of quiescence, this would gain time to design an adequate anti-cancer treatment $[64,74]$.

The induction of a moderate state of hypothermia is common in clinical practice. Body temperature is cooled to $35^{\circ} \mathrm{C}$ or even $32{ }^{\circ} \mathrm{C}$ in order to slow down metabolism and to preserve and extend the homeostasis in those cells that can recover from damages in the course of trauma or anoxia, or organ transplantation. The most oxygen and metabolically sensitive organ is the brain, representing about $2 \%$ of body weight but consuming $20 \%$ of oxygen [51]. Interestingly, however, all studies and meta-analyses have not yet provided evidence that cooling is beneficial for the brain, i.e., to improve defined outcome parameters when (i) hypothermia was used in the course of the treatment of brain injury. While results from some trials and experimental approaches seem very promising, to date, there remains a lack of "high-quality evidence that hypothermia is beneficial in the treatment" of patients with a traumatic brain injury [59] nor was there proven clinical evidence that (ii) induced hypothermia during neurosurgery would have been linked with a significant reduction in mortality or patients' neurological disability $[30,60]$. The protective effect of hypothermia (in terms of preventing the brain from hypoxic-ischemic damage) appears to be limited by the moderate degree of metabolic reduction that is attainable in the clinical setting.
Fig. 2 MR and body mass are allometrically related to each other, i.e., the MR of animals with high body mass is relatively lower than that of animals with low body mass. According to this relation, the minimum MR reached by very large mammals (hatched area) also defines the minimum MR in torpor. The difference between the euthermic $\mathrm{MR}$ and minimum MR in torpor (arrows) determines the MR reduction which is achievable by torpor (arrows) (from [94])

\section{What is the Theoretical „Hibernation Reserve“ of Human Beings?}

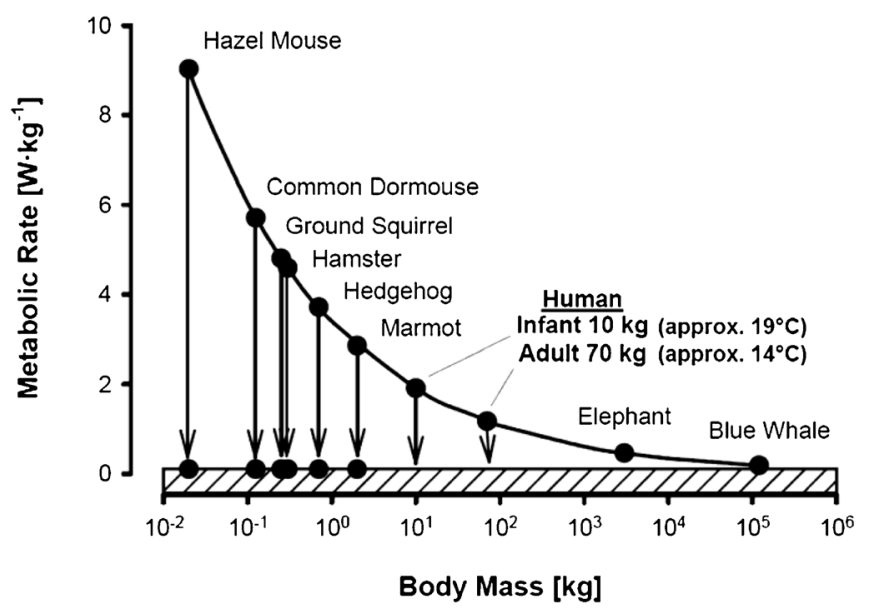


Moreover, the depth of cooling is limited by the adverse effects of reduced temperatures on several body functions. Therefore, an alternative protective strategy allowing an endogenous metabolic reduction independently of external cooling could be of great benefit in critical care medicine.

This lack of a stabilizing effect of induced hypothermia against tissue damage may not entirely reflect the conditions of such induction in healthy tissues. It indicates though that cooling is not equivalent to inducing a reduction of metabolism. In contrast, during natural torpor, the extent of hypometabolism is much larger than the effect of hypothermia $[33,76,106]$. Physiological processes are well controlled in natural torpor and can be sustained for a prolonged period of time. The use of this pathway to hypometabolism would offer a wide range of benefits in clinical practice as compared to artificial hypothermia, and will range from the acute prevention of metabolism deficiency in severely compromised and hypoxemic states (e.g., after trauma or asphyxia) to energy preservation in organs prepared for transplantation. Moreover, controlling cell energy turnover can not only help to control obesity and aging [117] processes, but also will allow limiting destructive catabolic states in severe illnesses such as sepsis and immobilization. Despite inactivity and starvation, hibernating animals do not suffer from atrophy of bone or musculoskeletal mass and strength $[50,68,88]$, to an extent which would be expected by disuse during several months of physical rest in their hibernaculum, or in humans during months of bed rest $[17,88]$. Interestingly, this might depend though on the size of the animal as some microstructural bone loss was observed in 13-lined ground squirrels during hibernation while this was not observed in larger hibernating mammals $[40,69]$. Thus, torpor strongly preserves organ and tissue integrity. This phenomenon could also be relevant during long spaceflights to counteract the effects of microgravity on disuse-related muscle and bone degeneration.

Organs which undergo severe changes during torpor and in hibernation, e.g., the intestine, lung, kidney, and also brain, recover very fast after arousal. For example, lung tissue in Syrian hamsters undergoes strong reorganization from torpor to the euthermic state: Autophagy highly increases in late torpor and during arousal most probably because of mTOR activation [105]. Reduced apoptosis and necrosis immediately after arousal from hibernation are hypothesized to underlie better maintenance of epithelial/endothelial barrier function [28]. In addition to anti-apoptotic proteins, potential molecular mechanisms that serve to resist tissue degradation during hibernation include activated serine/threonine kinase Akt [28] and the redox-sensitive transcription factor NF- $\mathrm{kB}$ [11]. More recently, increased formation of endogenous $\mathrm{H}_{2} \mathrm{~S}$, e.g., by induction of cystathionine-beta-synthase (CBS) expression during late torpor and early arousal, has been implicated as a mechanism protecting cells of hibernators from damage [19, 103, 104], e.g., increased renal expression of CBS reduces apoptosis and by this prevents kidney damage as it occurs in rats after rewarming from deep hypothermia [24].

The brain undergoes major remodeling in the torpid state during hibernation, i.e., reduction in number and height of synaptic boutons, and hyperphosphorylation of the neuroskeletal protein tau. These changes are rapidly reversed during arousals $[23,67,83,99]$, protecting the brain from loss of memory [16, $89,115]$. Elucidation of these processes could have strong impact on treatment of neurodegenerative diseases [82].

The heart plays a crucial role in the regulation of body homeostasis and circulation at all stages of torpor and is a priori highly susceptible to tissue and cellular damages. But during hypometabolic states in hibernation, either the large (bear) or smaller (squirrels) animals show sustained cardiac function - as measured by its output - reduced by $\sim 75 \%$ (bears) or by $\sim 97 \%$ (squirrels) [76]. In relation to animal size and core body temperature of the hibernating animal, frequency of the heart beat decreases, but remains at a sufficient and constant rate although the body temperature can be low $(<$ $10{ }^{\circ} \mathrm{C}$ ). This is related to a "reduced $\mathrm{Ca}^{2+}$ entry into the cell and concomitant enhancement of $\mathrm{Ca}^{2+}$ release from and reuptake by the sarcoplasmic reticulum" as Horii et al. [48] reviewed. A very recent controlled study on European ground squirrels quantified protein upregulations of antioxidant defense enzymes (e.g., manganese and copper/zinc superoxide dismutases) in the myocardium. Those hibernation-related phenotypes of the myocardium are hence characterized by changes in the $\mathrm{Ca}^{2+}$ homeostasis and strong upregulation of antioxidant enzymes [48, 97]. Moreover, unique expression pattern of cold-shock proteins can exert tissue protection during hibernation. Cold-inducible RNA-binding proteins, socalled CIRP, have been reported by Horii et al. [48] in the myocardium of hibernating hamsters, showing that CIRP expression in the hamster heart is "regulated at the level of alternative splicing, which would permit a rapid increment of functional CIRP when entering hibernation" [48]. Interestingly, CIRP also targets cancer-associated mRNAs and can modulate inflammation [63], which might both be of importance to other organs' protection during hibernation.

Beyond its protective effect against starvation, already decades ago it has been discovered that hibernation reduces the risk for radiation damage [73]. During hibernation, a remarkable resistance against radiation damage has been observed which could be helpful to counteract the radiation load during spaceflights $[14,116]$. Hypothermic conditions in which core body temperature decreases well below $37^{\circ} \mathrm{C}$ provide some protection against radiation-induced damage $[14,62]$ independent of whether hypothermia is applied before, during, or shortly after irradiation of cultured cells [62]. It was hypothesized that radioprotection during torpor may be the result of tissue hypoxia due to vasoconstriction [116] and decreased free radical production [21] as well as synergistically by reduced MR and a shift from glycolysis to lipolysis mimicking conditions during fasting [15]. 


\section{Occurrence of natural torpor among mammals}

These potential benefits are contrasted by the fact that humans do not spontaneously enter torpor and no way is known to turn humans to torpor. Species known to enter torpor are widely distributed in most mammalian groups ranging from monotremes through metatheria and the majority of eutherian orders including primates [31, 43]. The ability for torpor and its absence may even be observed in systematically closely related species like for instance in rodents where mice frequently become torpid whereas in rats (Rattus norvegicus) torpor has never been observed. The reason for this species-specific expression of torpor behavior among mammals is presently not known, though these differences are taken advantage of in experimental settings, respectively [91].

Hibernation with multiday torpor bouts is a seasonal behavior which is driven by an endogenous circannual clock. The persistence of this behavior even under constant light and temperature conditions over several years was the first proof of the existence of a circannual clock in animals [81]. Also, daily torpor may be a seasonal behavior, e.g., in mouse lemurs or Djungarian hamsters $[44,77]$ or it can occur at any time of the year as a facultative behavior in response to food shortage and/or moderate cold exposure, i.e., in several species of small mammals like mice or small marsupials [22, 32, 52, 53].

All results obtained on physiological, biochemical, and endocrine changes during torpor are based on the observation of spontaneous occurrence of torpor [85]. Generally, environmental temperature and nutritional conditions are important factors enhancing torpid states. However, the trigger actually inducing torpor, either exogenous or endogenous, is not known (Fig. 3). Many different species can undergo torpor, either in the hottest desert region [38] or in the wintery North, so at every longitude and latitude and in all seasons. From an evolutionary point of view, torpor represents a strategy to cope with adverse environmental situations ("stressors") as are cold or heat and dryness and lack of food availability. Thus, torpor is not restricted to hibernation but also may occur in tropical or subtropical habitat (e.g., the Malagassian lemurs [77]) to survive periods of dryness or in the case of daily torpor to safe energy.

This high capacity for metabolic control and changes in energy expenditure is an awesome example for "phenotypic plasticity." However, it is an open question to which extent humans are capable of a similar phenotypic plasticity. At least, some phenotypic plasticity is seen in premature born humans [93], as well as in the protective mechanism of organs (e.g., brain, liver, kidney) to overcome damage, malperfusion, and malnutritional states by the principle of "preconditioning" (see below).

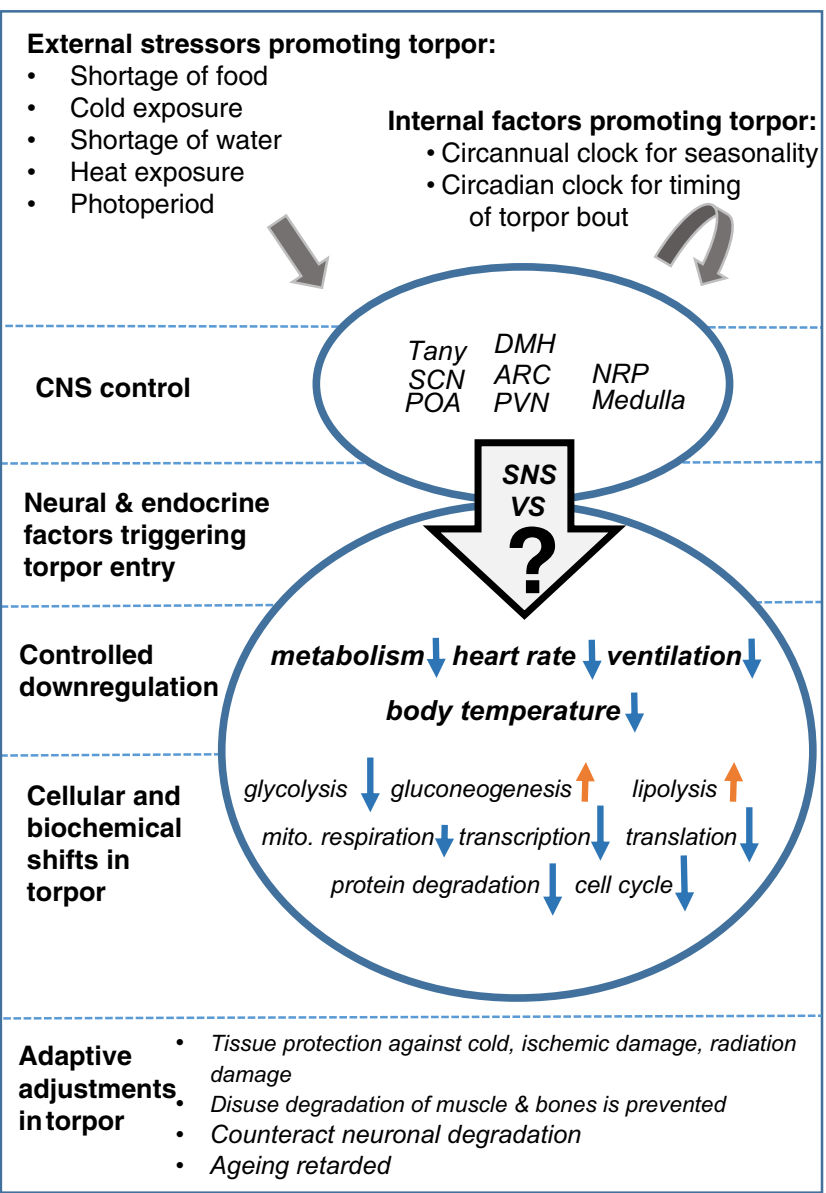

Fig. 3 Summary of physiological changes during torpor in mammals. The central control of torpor includes activity of several brain areas mainly located in the hypothalamus. POA, the preoptic area, plays an important role in control of body temperature and its adjustment to lower levels in torpor. $\mathrm{SCN}$, the suprachiasmatic nucleus, is controlling circadian rhythms and thus the timing of torpor bouts. PVN, the paraventricular nucleus, is involved in the control of food intake and response to environmental change. ARC, the arcuate nucleus, plays a leading role in homeostasis and contains specific neurons related to the control of feeding and metabolism. DMH, the dorsomedial hypothalamus, is involved in the control of feeding, body weight regulation, and circadian activity, and tightly linked with other neuronal areas related to these functions. NRP, the nucleus raphe pallidus, is tightly linked with hypothalamic neuronal areas, e.g., the PVN, and is involved in control of body temperature, heart rate, and ventilation. Tany, tanycites, are ependymal cells in the third ventricle transferring chemical signal from the cerebrospinal fluid to the brain neurons. Their ability to control thyroid hormone metabolism may be of significance for the expression of torpor behavior. The medulla contains several groups of neurons which are essential for most autonomic functions including ventilation and heart rate which undergo major changes during torpor. For further details of physiological, biochemical, and cellular adjustments during torpor, see text

\section{Approaches to induce torpor in non-hibernating mammals}

Although the mechanisms of torpor induction still are not known, some environmental factors involved in onset of seasonal torpor in hibernation have been identified, i.e., food 
shortage, temperature, and diurnal light and sleep cycles (Fig. 3). In addition, physiological readiness of the neuro-endocrine system is required [52]. Experimental modification of these factors revealed their significance but their action in concert still is a mystery.

In accord with the findings that food availability is one of the factors influencing onset of torpor, injection of leptin, mimicking large fat stores, reduced the duration and depth of daily torpor bouts [33, 34], while ghrelin injections, mimicking the need for food intake, enhance torpor occurrence in mice [35].

This underlines the significance of CNS and endocrine factors involved for the control of food intake for seasonal acclimation and the disposition to enter torpor (for review, see [52]). New findings in bears indicate that large mammals seem to "cycle" into a torpid state over weeks by slow but incrementally downregulated MR, with intermittent increases of MR [27].

Three parts of the nervous system have been identified to play a substantial role for control of MR and body temperature:

- The hypothalamus coordinating the majority of autonomic responses [46, 49, 80, 101]

- The Raphe pallidus nucleus in the brain stem which receives afferent inputs from several hypothalamic areas and projects to the spinal cord $[13,72]$. It participates in the control of blood pressure, thermoregulatory heat production in brown fat, activity of heart, skeletal muscle, and smooth muscles, and, supposedly the thyroid and liver

- The sympathetic nervous system (SNS) is linking hypothalamic as well as extrahypothalamic areas and is strongly involved in the control of blood flow, ventilation and MR of peripheral organs, in torpor initiation, torpor maintenance as well as in arousal [7, 102].

Several attempts have been made to induce a torpor-like state in non-hibernators using drugs [5, 6]. Until now, the use of $\mathrm{H}_{2} \mathrm{~S}, 5^{\prime}$-AMP and metamizol (an inhibitor of T4 deiodinization) and thyronamine was shown to be successful in reducing physiological parameters in mice and Djungarian hamsters $[4,8]$. These are species which show torpor spontaneously as well, whereas other species did not respond in a similar way. Overall, the present findings do not give a clear picture about drugs reducing MR and changing metabolic pathways which could mimic natural torpor $[5,6]$.

\section{Human hibernation: an achievable goal?}

Hibernation, torpor, and other hypometabolic states are widespread in mammals (and other vertebrates), in small (less than $10 \mathrm{~kg}$ ) as well as in large animals (i.e., bear, deer). Up to now no unique factors or genes or neuro-endocrine properties have been identified for this state, suggesting that also humans have the potential for this physiological state. Hypometabolism in mammalian fetuses at normothermic conditions may provide a model for torpor in humans.

While small mammals, e.g., the Djungarian hamster, dormouse, and ground squirrel, reduce their temperature almost to the level of ambient temperature and need up to several hours for arousal from the torpid state, in larger mammals including bear and deer, body temperature remains well above $30^{\circ} \mathrm{C}$, but as shown for the brown bear, metabolism is reduced to $25 \%$ of summer activity [114]. They do not interrupt torpor by repeated arousals and torpor can be terminated within a short period of time. "High temperature torpor" (hypometabolism) is the preferred scheme for humans, because it is maintained continuously without energetically costly interruptions [20].

Humans, like other mammals, lower their metabolic rate and body temperature during sleep. Most pronounced changes were observed in Australian natives who were adapted to sleep without cover at low temperatures at night [39]. Pronounced depressions were also observed being associated with the chronic fatigue syndrome [75] or during deep meditation $[45,109]$. The metabolic depression observed in these cases is much less than would be expected during a torpor bout. It demonstrates the potential for MR reduction in humans, but it is still uncertain whether and how these observations compare with natural torpor.

Analogies exist between the sequence of events occurring during entrance into torpor and adaptations to hypoxia [36] as to the diving reflex in aquatic mammals and humans $[61,79]$ or in human fetuses being exposed to birth asphyxia [93]. New observations seen in bears guide understanding the pattern how induction is occurring [27]. Moreover, preconditioning - a condition of non-damaging stimulus to promote a higher (transient, permanent) tolerance of tissues to a subsequent more severe/ longer lasting challenge - seems also to work in humans and has strong parallels to metabolic changes in hibernating animals $[18,57,58,70,84,98,108]$. The (pre-)conditioning is furthermore one of the most efficient tools in biology to adapt to new environmental challenges on the cell organelles' metabolic level and it seems to be effective in humans as well. Transient metabolic shutdown of organ metabolism, e.g., of the kidney, in the course of severe inflammatory disease and shock conditions is considered a state similar to hibernation [71]. For preconditioning, these benefits are regulated through the (i) preservation of energy in the cell, and hereby the (ii) preservation of cell homeostasis, and are linked to a distinct set of genes of which the expression was dampened in response to the preconditioning procedure. In particular, those genes affect glucose metabolism, protein turnover, and cell cycle [2].

Altogether, these effects "mimic hibernation and hypoxia tolerance suggesting the existence of a conserved endogenous genomic programme of physiological adaptations to oxygen limitation that improve survival" [98]. Since preconditioning can be achieved also by pharmacological interventions or 
hypoxic conditions - which have all shown their efficacythese observations and conditions may help enable the first steps toward torpor in humans $[41,87]$. The next steps have to be based on deeper knowledge of neuro-endocrine changes inducing torpor. The road map on the way transferring astronauts to torpor or a torpor-like state will include induction of torpor on animals which normally do not develop extensive MR reduction (e.g., rats, pigs). In parallel however - and because of the yet unknown risks of torpor in humans - the endeavor of manned mission to outer space needs to be accompanied also by technical developments, either in the spacecraft propulsion or spacious habitat design, including the implementation of artificial gravity. Moreover, the continuous increase in knowledge on the mitigation of the health risks under conditions of space environment will have to accompany and also help the new and gamechanging venues enabling hibernation of a space crew.

Acknowledgements This article is based on the discussions of an ESA topical team (contracts No. 4000 111354/14NL/MV and no. 4000117771/ 16/NL) with the following members: Carey, H.V., Dept of Comparative Biosciences, School of Veterinary Medicine, Director UW-Biotron, University of Wisconsin, USA; Cerri, M., Department of Human and General Physiology, School of Medicine, University of Bologna, Italy; Daan, S., Niko Tinbergen Distinguished Chair in Behavioural Biology, University of Groningen, Netherlands; Drew K.L., Department of Chemistry and Biochemistry, Institute of Arctic Biology; University of Alaska Fairbanks, USA; Henning, R.H., Dept. Clinical Pharmacy \& Pharmacology, University Medical Center Groningen, Netherlands; Herwig, A., Institute of Neurobiology, Ulm University, Germany; Hut, R., Chronobiology Unit, Center for Behavior and Neuroscience, University of Groningen, The Netherlands; Ruf, T., Research Institute for Wildlife Ecology, University of Veterinary Medicine, Vienna; Vyazovskiy, V., University of Oxford, Physiology, Anatomy \& Genetics, UK. Support and encouragement of the topical team and of ongoing research by Marc Heppener, Jennifer Ngo-Anh, Thomas Reiter and Leopold Summerer (European Space Agency, ESTEC, Noordwijk, The Netherlands, is gratefully acknowledged.

The authors thank Dr. Dominique Moser, Laboratory "Translational Research Stress and Immunity," Department of Anesthesiology, Hospital of the University of Munich, for her excellent editorial support.

Funding information A.C. is supported by the Ministry of Economics and Energy (BMWi) as handled by the German Space Agency (DLR grant 50WB1622).

Open Access This article is distributed under the terms of the Creative Commons Attribution 4.0 International License (http:// creativecommons.org/licenses/by/4.0/), which permits unrestricted use, distribution, and reproduction in any medium, provided you give appropriate credit to the original author(s) and the source, provide a link to the Creative Commons license, and indicate if changes were made.

Publisher's Note Springer Nature remains neutral with regard to jurisdictional claims in published maps and institutional affiliations.

\section{References}

1. Andrews MT (2004) Genes controlling the metabolic switch in hibernating mammals. Biochem Soc Trans 32:1021-1024. https:// doi.org/10.1042/bst0321021
2. Andrews MT, Russeth KP, Drewes LR, Henry PG (2009) Adaptive mechanisms regulate preferred utilization of ketones in the heart and brain of a hibernating mammal during arousal from torpor. Am J Physiol Regul Integr Comp Physiol 296:R383R393. https://doi.org/10.1152/ajpregu.90795.2008

3. Berg von Linde M, Arevstrom L, Frobert O (2015) Insights from the den: how hibernating bears may help us understand and treat human disease. Clin Transl Sci 8:601-605. https://doi.org/10.1111/cts.12279

4. Blackstone E, Morrison M, Roth MB (2005) H2S induces a suspended animation-like state in mice. Science 308:518. https:// doi.org/10.1126/science.1108581

5. Bouma HR, Kroese FG, Kok JW, Talaei F, Boerema AS, Herwig A, Draghiciu O, van Buiten A, Epema AH, van Dam A, Strijkstra AM, Henning RH (2011) Low body temperature governs the decline of circulating lymphocytes during hibernation through sphingosine-1-phosphate. Proc Natl Acad Sci U S A 108:20522057. https://doi.org/10.1073/pnas.1008823108

6. Bouma HR, Verhaag EM, Otis JP, Heldmaier G, Swoap SJ, Strijkstra AM, Henning RH, Carey HV (2012) Induction of torpor: mimicking natural metabolic suppression for biomedical applications. J Cell Physiol 227:1285-1290. https://doi.org/10.1002/jcp.22850

7. Braulke LJ, Heldmaier G (2010) Torpor and ultradian rhythms require an intact signalling of the sympathetic nervous system. Cryobiology 60:198-203. https://doi.org/10.1016/j.cryobiol.2009.11.001

8. Braulke LJ, Klingenspor M, DeBarber A, Tobias SC, Grandy DK, Scanlan TS, Heldmaier G (2008) 3-Iodothyronamine: a novel hormone controlling the balance between glucose and lipid utilisation. J Comp Physiol B 178:167-177. https://doi.org/10. 1007/s00360-007-0208-x

9. Brown JC, Gerson AR, Staples JF (2007) Mitochondrial metabolism during daily torpor in the dwarf Siberian hamster: role of active regulated changes and passive thermal effects. Am J Physiol Regul Integr Comp Physiol 293:R1833-R1845. https:// doi.org/10.1152/ajpregu.00310.2007

10. Carey HV, Andrews MT, Martin SL (2003) Mammalian hibernation: cellular and molecular responses to depressed metabolism and low temperature. Physiol Rev 83:1153-1181. https://doi.org/ 10.1152/physrev.00008.2003

11. Carey HV, Frank CL, Seifert JP (2000) Hibernation induces oxidative stress and activation of NK-kappaB in ground squirrel intestine. J Comp Physiol B 170:551-559

12. Cerri M (2017) The central control of energy expenditure: exploiting torpor for medical applications. Annu Rev Physiol 79:167-186. https://doi.org/10.1146/annurev-physiol-022516-034133

13. Cerri M, Mastrotto M, Tupone D, Martelli D, Luppi M, Perez E, Zamboni G, Amici R (2013) The inhibition of neurons in the central nervous pathways for thermoregulatory cold defense induces a suspended animation state in the rat. J Neurosci 33:29842993. https://doi.org/10.1523/jneurosci.3596-12.2013

14. Cerri M, Tinganelli W, Negrini M, Helm A, Scifoni E, Tommasino F, Sioli M, Zoccoli A, Durante M (2016) Hibernation for space travel: impact on radioprotection. Life Sci Space Res (Amst) 11:19. https://doi.org/10.1016/j.lssr.2016.09.001

15. Cheng CW, Adams GB, Perin L, Wei M, Zhou X, Lam BS, Da Sacco S, Mirisola M, Quinn DI, Dorff TB, Kopchick JJ, Longo VD (2014) Prolonged fasting reduces IGF-1/PKA to promote hematopoieticstem-cell-based regeneration and reverse immunosuppression. Cell Stem Cell 14:810-823. https://doi.org/10.1016/j.stem.2014.04.014

16. Clemens LE, Heldmaier G, Exner C (2009) Keep cool: memory is retained during hibernation in Alpine marmots. Physiol Behav 98: 78-84. https://doi.org/10.1016/j.physbeh.2009.04.013

17. Cotton CJ (2016) Skeletal muscle mass and composition during mammalian hibernation. J Exp Biol 219:226-234. https://doi.org/ 10.1242/jeb. 125401

18. Cuomo O, Pignataro G, Sirabella R, Molinaro P, Anzilotti S, Scorziello A, Sisalli MJ, Di Renzo G, Annunziato L (2016) 
Sumoylation of LYS590 of NCX3 f-Loop by SUMO1 participates in brain neuroprotection induced by ischemic preconditioning. Stroke 47:1085-1093. https://doi.org/10.1161/strokeaha.115.012514

19. D'Alessandro A, Nemkov T, Bogren LK, Martin SL, Hansen KC (2017) Comfortably numb and back: plasma metabolomics reveals biochemical adaptations in the hibernating 13-lined ground squirrel. J Proteome Res 16:958-969. https://doi.org/10.1021/acs. jproteome.6b00884

20. Daan S, Barnes BM, Strijkstra AM (1991) Warming up for sleep? Ground squirrels sleep during arousals from hibernation. Neurosci Lett 128:265-268

21. Dang B, Yang Y, Zhang E, Li W, Mi X, Meng Y, Yan S, Wang Z, Wei W, Shao C, Xing R, Lin C (2014) Simulated microgravity increases heavy ion radiation-induced apoptosis in human B lymphoblasts. Life Sci 97:123-128. https://doi.org/10.1016/j.lfs.2013.12.008

22. Dausmann KH, Glos J, Ganzhorn JU, Heldmaier G (2004) Physiology: hibernation in a tropical primate. Nature 429:825826. https://doi.org/10.1038/429825a

23. Dave KR, Christian SL, Perez-Pinzon MA, Drew KL (2012) Neuroprotection: lessons from hibernators. Comp Biochem Physiol B Biochem Mol Biol 162:1-9. https://doi.org/10.1016/j. cbpb.2012.01.008

24. Dugbartey GJ, Talaei F, Houwertjes MC, Goris M, Epema AH, Bouma HR, Henning RH (2015) Dopamine treatment attenuates acute kidney injury in a rat model of deep hypothermia and rewarming - the role of renal H2S-producing enzymes. Eur J Pharmacol 769:225-233. https://doi.org/10.1016/j.ejphar.2015.11.022

25. Elvert R, Heldmaier G (2005) Cardiorespiratory and metabolic reactions during entrance into torpor in dormice, Glis glis. J Exp Biol 208:1373-1383. https://doi.org/10.1242/jeb.01546

26. Epperson LE, Rose JC, Carey HV, Martin SL (2010) Seasonal proteomic changes reveal molecular adaptations to preserve and replenish liver proteins during ground squirrel hibernation. Am J Physiol Regul Integr Comp Physiol 298:R329-R340. https://doi. org/10.1152/ajpregu.00416.2009

27. Evans AL, Singh NJ, Friebe A, Arnemo JM, Laske TG, Frobert O, Swenson JE, Blanc S (2016) Drivers of hibernation in the brown bear. Front Zool 13:7. https://doi.org/10.1186/s12983-016-0140-6

28. Fleck CC, Carey HV (2005) Modulation of apoptotic pathways in intestinal mucosa during hibernation. Am J Physiol Regul Integr Comp Physiol 289:R586-r595. https://doi.org/10.1152/ajpregu. 00100.2005

29. Frerichs KU, Hallenbeck JM (1998) Hibernation in ground squirrels induces state and species-specific tolerance to hypoxia and aglycemia: an in vitro study in hippocampal slices. J Cereb Blood Flow Metab 18:168-175. https://doi.org/10.1097/ 00004647-199802000-00007

30. Galvin IM, Levy R, Boyd JG, Day AG, Wallace MC (2015) Cooling for cerebral protection during brain surgery. Cochrane Database Syst Rev 1:Cd006638. https://doi.org/10.1002/ 14651858.CD006638.pub3

31. Geiser F (2004) Metabolic rate and body temperature reduction during hibernation and daily torpor. Annu Rev Physiol 66:239274. https://doi.org/10.1146/annurev.physiol.66.032102.115105

32. Geiser F (2007) Yearlong hibernation in a marsupial mammal. Naturwissenschaften 94:941-944. https://doi.org/10.1007/ s00114-007-0274-7

33. Geiser F, Currie SE, O'Shea KA, Hiebert SM (2014) Torpor and hypothermia: reversed hysteresis of metabolic rate and body temperature. Am J Physiol Regul Integr Comp Physiol 307:R1324 R1329. https://doi.org/10.1152/ajpregu.00214.2014

34. Geiser F, Kortner G, Schmidt I (1998) Leptin increases energy expenditure of a marsupial by inhibition of daily torpor. Am J Phys 275:R1627-R1632

35. Gluck EF, Stephens N, Swoap SJ (2006) Peripheral ghrelin deepens torpor bouts in mice through the arcuate nucleus neuropeptide Y signaling pathway. Am J Physiol Regul Integr Comp Physiol 291:R1303-R1309. https://doi.org/10.1152/ ajpregu.00232.2006

36. Gorr TA (2017) Hypometabolism as the ultimate defence in stress response: how the comparative approach helps understanding of medically relevant questions. Acta Physiol (Oxf) 219:409-440. https://doi.org/10.1111/apha.12747

37. Griko Y, Regan MD (2018) Synthetic torpor: a method for safely and practically transporting experimental animals aboard spaceflight missions to deep space. Life Sci Space Res (Amst) 16:101107. https://doi.org/10.1016/j.1ssr.2018.01.002

38. Grimpo K, Legler K, Heldmaier G, Exner C (2013) That's hot: golden spiny mice display torpor even at high ambient temperatures. J Comp Physiol B 183:567-581. https://doi.org/10.1007/ s00360-012-0721-4

39. Hammel HT, Elsner RW, LeMessurier DH, Andersen TH, Milan FA (1959) Thermal and metabolic responses of the Australian aborigines exposed to moderate cold in summer. J Appl Physiol 14:605-615

40. Hargens AR, Vico L (2016) Long-duration bed rest as an analog to microgravity. J Appl Physiol (1985) 120:891-903. https://doi.org/ 10.1152/japplphysiol.00935.2015

41. Hausenloy DJ, Barrabes JA, Botker HE, Davidson SM, Di Lisa F, Downey J, Engstrom T, Ferdinandy P, Carbrera-Fuentes HA, Heusch G, Ibanez B, Iliodromitis EK, Inserte J, Jennings R, Kalia N, Kharbanda R, Lecour S, Marber M, Miura T, Ovize M, PerezPinzon MA, Piper HM, Przyklenk K, Schmidt MR, Redington A, Ruiz-Meana M, Vilahur G, Vinten-Johansen J, Yellon DM, GarciaDorado D (2016) Ischaemic conditioning and targeting reperfusion injury: a 30 year voyage of discovery. Basic Res Cardiol 111:70. https://doi.org/10.1007/s00395-016-0588-8

42. Heldmaier G, Klingenspor M, Werneyer M, Lampi BJ, Brooks SP, Storey KB (1999) Metabolic adjustments during daily torpor in the Djungarian hamster. Am J Phys 276:E896-E906

43. Heldmaier G, Ortmann S, Elvert R (2004) Natural hypometabolism during hibernation and daily torpor in mammals. Respir Physiol Neurobiol 141:317-329. https://doi.org/10.1016/j.resp.2004.03.014

44. Heldmaier G, Steinlechner S (1981) Seasonal pattern and energetics of short daily torpor in the Djungarian hamster, Phodopus sungorus. Oecologia 48:265-270. https://doi.org/10.1007/ bf00347975

45. Heller HC, Elsner R, Rao N (1987) Voluntary hypometabolism in an Indian Yogi. J Therm Biol 12:171-173

46. Heller HC, Hammel HT (1972) CNS control of body temperature during hibernation. Comp Biochem Physiol A Comp Physiol 41: 349-359

47. Herwig A, Saboureau M, Pevet P, Steinlechner S (2007) Daily torpor affects the molecular machinery of the circadian clock in Djungarian hamsters (Phodopus sungorus). Eur J Neurosci 26: 2739-2746. https://doi.org/10.1111/j.1460-9568.2007.05927.x

48. Horii Y, Shiina T, Shimizu Y (2018) The mechanism enabling hibernation in mammals. Adv Exp Med Biol 1081:45-60. https://doi.org/10.1007/978-981-13-1244-1_3

49. Ishida N (2009) Role of PPARalpha in the control of torpor through FGF21-NPY pathway: from circadian clock to seasonal change in mammals. PPAR Res 2009:412949-412945. https:// doi.org/10.1155/2009/412949

50. Ivakine EA, Cohn RD (2014) Maintaining skeletal muscle mass: lessons learned from hibernation. Exp Physiol 99:632-637. https://doi.org/10.1113/expphysiol.2013.074344

51. Jain V, Langham MC, Wehrli FW (2010) MRI estimation of global brain oxygen consumption rate. J Cereb Blood Flow Metab 30: 1598-1607. https://doi.org/10.1038/jcbfm.2010.49

52. Jastroch M, Giroud S, Barrett P, Geiser F, Heldmaier G, Herwig A (2016) Seasonal control of mammalian energy balance: recent 
advances in the understanding of daily torpor and hibernation. $\mathrm{J}$ Neuroendocrinol 28. https://doi.org/10.1111/jne.12437

53. Kortner G, Pavey CR, Geiser F (2008) Thermal biology, torpor, and activity in free-living mulgaras in arid zone Australia during the winter reproductive season. Physiol Biochem Zool 81:442451. https://doi.org/10.1086/589545

54. Kortner G, Rojas AD, Geiser F (2010) Thermal biology, torpor use and activity patterns of a small diurnal marsupial from a tropical desert: sexual differences. J Comp Physiol B 180:869-876. https:// doi.org/10.1007/s00360-010-0459-9

55. Larkin JE, Heller HC Sleep after arousal from hibernation is not homeostatically regulated. Am J Physiol 276:R522-R529

56. Larson J, Drew KL, Folkow LP, Milton SL, Park TJ (2014) No oxygen? No problem! Intrinsic brain tolerance to hypoxia in vertebrates. J Exp Biol 217:1024-1039. https://doi.org/10.1242/jeb.085381

57. Lee YJ, Castri P, Bembry J, Maric D, Auh S, Hallenbeck JM (2009) SUMOylation participates in induction of ischemic tolerance. J Neurochem 109:257-267. https://doi.org/10.1111/j.14714159.2009.05957.x

58. Lee YJ, Miyake S, Wakita H, McMullen DC, Azuma Y, Auh S, Hallenbeck JM (2007) Protein SUMOylation is massively increased in hibernation torpor and is critical for the cytoprotection provided by ischemic preconditioning and hypothermia in SHSY5Y cells. J Cereb Blood Flow Metab 27:950-962. https:// doi.org/10.1038/sj.jcbfm.9600395

59. Lewis SR, Evans DJ, Butler AR, Schofield-Robinson OJ, Alderson P (2017) Hypothermia for traumatic brain injury. Cochrane Database Syst Rev 9:Cd001048. https://doi.org/10. 1002/14651858.CD001048.pub5

60. Li LR, You C, Chaudhary B (2016) Intraoperative mild hypothermia for postoperative neurological deficits in people with intracranial aneurysm. Cochrane Database Syst Rev 3:Cd008445. https:// doi.org/10.1002/14651858.CD008445.pub3

61. Lindholm P, Lundgren CE (2009) The physiology and pathophysiology of human breath-hold diving. J Appl Physiol (1985) 106: 284-292. https://doi.org/10.1152/japplphysiol.90991.2008

62. Lisowska H, Brehwens K, Zolzer F, Wegierek-Ciuk A, Czub J, Lankoff A, Haghdoost S, Wojcik A (2014) Effect of hypothermia on radiation-induced micronuclei and delay of cell cycle progression in TK6 cells. Int J Radiat Biol 90:318-324. https://doi.org/10. 3109/09553002.2014.887233

63. Lujan DA, Ochoa JL, Hartley RS (2018) Cold-inducible RNA binding protein in cancer and inflammation. Wiley Interdiscip Rev RNA 9:e1462. https://doi.org/10.1002/wrna.1462

64. Lund AW (2017) Winter is coming: tumor cells go into hibernation. Sci Transl Med 9:eaam6063. https://doi.org/10.1126/ scitranslmed.aam6063

65. Lyman CP (1984) Pharmacological aspects of mammalian hibernation. Pharmacol Ther 25:371-393

66. Machado-Ferrer Y, Estevez M, Machado C, Hernandez-Cruz A, Carrick FR, Leisman G, Melillo R, Defina P, Chinchilla M, Machado Y (2013) Heart rate variability for assessing comatose patients with different Glasgow Coma Scale scores. Clin Neurophysiol 124:589-597. https://doi.org/10.1016/j.clinph. 2012.09.008

67. Magarinos AM, McEwen BS, Saboureau M, Pevet P (2006) Rapid and reversible changes in intrahippocampal connectivity during the course of hibernation in European hamsters. Proc Natl Acad Sci U S A 103:18775-18780. https://doi.org/10.1073/ pnas.0608785103

68. McGee-Lawrence ME, Carey HV, Donahue SW (2008) Mammalian hibernation as a model of disuse osteoporosis: the effects of physical inactivity on bone metabolism, structure, and strength. Am J Physiol Regul Integr Comp Physiol 295:R1999_ R2014. https://doi.org/10.1152/ajpregu.90648.2008
69. McGee-Lawrence ME, Wojda SJ, Barlow LN, Drummer TD, Castillo AB, Kennedy O, Condon KW, Auger J, Black HL, Nelson OL, Robbins CT, Donahue SW (2009) Grizzly bears (Ursus arctos horribilis) and black bears (Ursus americanus) prevent trabecular bone loss during disuse (hibernation). Bone 45: 1186-1191. https://doi.org/10.1016/j.bone.2009.08.011

70. Miyake S, Wakita H, Bernstock JD, Castri P, Ruetzler C, Miyake J, Lee YJ, Hallenbeck JM (2015) Hypophosphorylation of ribosomal protein $\mathrm{S} 6$ is a molecular mechanism underlying ischemic tolerance induced by either hibernation or preconditioning. $\mathrm{J}$ Neurochem 135:943-957. https://doi.org/10.1111/jnc.13368

71. Mongardon N, Dyson A, Singer M (2009) Is MOF an outcome parameter or a transient, adaptive state in critical illness? Curr Opin Crit Care 15:431-436. https://doi.org/10.1097/MCC. 0b013e3283307a3b

72. Morrison SF, Madden CJ, Tupone D (2014) Central neural regulation of brown adipose tissue thermogenesis and energy expenditure. Cell Metab 19:741-756. https://doi.org/10.1016/j.cmet.2014.02.007

73. Musacchia XJ, Barr RE (1968) Survival of whole-body-irradiated hibernating and active ground squirrels; Citellus tridecemlineatus. Radiat Res 33:348-356

74. Muzes G, Sipos F (2017) Metastatic cell dormancy and re-activation: an overview on series of molecular events critical for cancer relapse. Anti Cancer Agents Med Chem 17:472-482. https://doi. org/10.2174/1871520616666160901145857

75. Naviaux RK, Naviaux JC, Li K, Bright AT, Alaynick WA, Wang L, Baxter A, Nathan N, Anderson W, Gordon E (2016) Metabolic features of chronic fatigue syndrome. Proc Natl Acad Sci U S A 113:E5472-E5480. https://doi.org/10.1073/pnas.1607571113

76. Nelson OL, Robbins CT (2015) Cardiovascular function in large to small hibernators: bears to ground squirrels. J Comp Physiol B 185:265-279. https://doi.org/10.1007/s00360-014-0881-5

77. Ortmann S, Heldmaier G, Schmid J, Ganzhorn JU (1997) Spontaneous daily torpor in Malagasy mouse lemurs. Naturwissenschaften 84:28-32

78. Pagel JI, Chouker A (2016) Effects of isolation and confinement on humans-implications for manned space explorations. J Appl Physiol (1985) 120:1449-1457. https://doi.org/10.1152/ japplphysiol.00928.2015

79. Panneton WM (2013) The mammalian diving response: an enigmatic reflex to preserve life? Physiology (Bethesda) 28:284-297. https://doi.org/10.1152/physiol.00020.2013

80. Park JH, Dark J (2007) Fos-like immunoreactivity in Siberian hamster brain during initiation of torpor-like hypothermia induced by 2DG. Brain Res 1161:38-45. https://doi.org/10.1016/j. brainres.2007.05.040

81. Pengelley ET, Asmundson SJ (1970) The effect of light on the free running circannual rhythm of the golden-mantled ground squirrel, Citellus lateralis. Comp Biochem Physiol 32:155-160

82. Peretti D, Bastide A, Radford H, Verity N, Molloy C, Martin MG, Moreno JA, Steinert JR, Smith T, Dinsdale D, Willis AE, Mallucci GR (2015) RBM3 mediates structural plasticity and protective effects of cooling in neurodegeneration. Nature 518:236-239. https://doi.org/10.1038/nature14142

83. Popov VI, Bocharova LS (1992) Hibernation-induced structural changes in synaptic contacts between mossy fibres and hippocampal pyramidal neurons. Neuroscience 48:53-62

84. Quinones QJ, Ma Q, Zhang Z, Barnes BM, Podgoreanu MV (2014) Organ protective mechanisms common to extremes of physiology: a window through hibernation biology. Integr Comp Biol 54:497-515. https://doi.org/10.1093/icb/icu047

85. Quinones QJ, Zhang Z, Ma Q, Smith MP, Soderblom E, Moseley MA, Bain J, Newgard CB, Muehlbauer MJ, Hirschey M, Drew KL, Barnes BM, Podgoreanu MV (2016) Proteomic profiling reveals adaptive responses to surgical myocardial ischemiareperfusion in hibernating Arctic ground squirrels compared to 
rats. Anesthesiology 124:1296-1310. https://doi.org/10.1097/aln. 0000000000001113

86. Ratigan ED, McKay DB (2016) Exploring principles of hibernation for organ preservation. Transplant Rev (Orlando) 30:13-19. https://doi.org/10.1016/j.trre.2015.08.002

87. Ravingerova T, Farkasova V, Griecsova L, Carnicka S, Murarikova M, Barlaka E, Kolar F, Bartekova M, Lonek L, Slezak J, Lazou A (2016) Remote preconditioning as a novel "conditioning" approach to repair the broken heart: potential mechanisms and clinical applications. Physiol Res 65(Suppl 1): S55-S64

88. Reilly BD, Franklin CE (2016) Prevention of muscle wasting and osteoporosis: the value of examining novel animal models. J Exp Biol 219:2582-2595. https://doi.org/10.1242/jeb.128348

89. Ruczynski I, Clarin TM, Siemers BM (2014) Do greater mouse-eared bats experience a trade-off between energy conservation and learning? J Exp Biol 217:4043-4048. https://doi.org/10.1242/jeb.106336

90. Ruf T, Geiser F (2015) Daily torpor and hibernation in birds and mammals. Biol Rev Camb Philos Soc 90:891-926. https://doi.org/ 10.1111/brv.12137

91. Shimaoka H, Kawaguchi T, Morikawa K, Sano Y, Naitou K, Nakamori H, Shiina T, Shimizu Y (2018) Induction of hibernation-like hypothermia by central activation of the A1 adenosine receptor in a non-hibernator, the rat. J Physiol Sci 68:425430. https://doi.org/10.1007/s12576-017-0543-y

92. Simpson EJ, Debevec T, Eiken O, Mekjavic I, Macdonald IA (2016) PlanHab: the combined and separate effects of 16 days of bed rest and normobaric hypoxic confinement on circulating lipids and indices of insulin sensitivity in healthy men. J Appl Physiol (1985) 120:947955. https://doi.org/10.1152/japplphysiol.00897.2015

93. Singer D (1999) Neonatal tolerance to hypoxia: a comparativephysiological approach. Comp Biochem Physiol A Mol Integr Physiol 123:221-234

94. Singer D (2006) Human hibernation for space flight: utopistic vision or realistic possibility? J Brit Interplanet Soc 59:139-143

95. Singer D, Bretschneider HJ (1990) Metabolic reduction in hypothermia: pathophysiological problems and natural examples-part 1. Thorac Cardiovasc Surg 38:205-211. https://doi.org/10.1055/s2007-1014020

96. Singer D, Bretschneider HJ (1990) Metabolic reduction in hypothermia: pathophysiological problems and natural examples-part 2. Thorac Cardiovasc Surg 38:212-219. https://doi.org/10.1055/s2007-1014179

97. Stancic A, Jankovic A, Korac A, Cirovic D, Otasevic V, Storey KB, Korac B (2018) A lesson from the oxidative metabolism of hibernator heart: possible strategy for cardioprotection. Comp Biochem Physiol B Biochem Mol Biol 219-220:1-9. https://doi. org/10.1016/j.cbpb.2018.02.004

98. Stenzel-Poore MP, Stevens SL, Xiong Z, Lessov NS, Harrington CA, Mori M, Meller R, Rosenzweig HL, Tobar E, Shaw TE, Chu X, Simon RP (2003) Effect of ischaemic preconditioning on genomic response to cerebral ischaemia: similarity to neuroprotective strategies in hibernation and hypoxia-tolerant states. Lancet 362:1028-1037. https://doi.org/10.1016/s0140-6736(03)14412-1

99. Stieler JT, Bullmann T, Kohl F, Toien O, Bruckner MK, Hartig W, Barnes BM, Arendt T (2011) The physiological link between metabolic rate depression and tau phosphorylation in mammalian hibernation. PLoS One 6:e14530. https://doi.org/10.1371/journal. pone. 0014530

100. Storey KB, Heldmaier G, Rider MH (2010) Mammalian hibernation: physiology, cell signaling, and gene controls on metabolic rate depression. In: ELe a (ed) Dormancy and resistance in harsh environments. Springer, Heidelberg, pp 227-252

101. Swoap SJ (2008) Why one enters torpor: focus on "NPY Y1 receptor antagonist prevents NPY-induced torpor-like hypothermia in cold-acclimated Siberian hamsters". Am J Physiol Regul
Integr Comp Physiol 294:R234-R235. https://doi.org/10.1152/ ajpregu.00773.2007

102. Swoap SJ, Weinshenker D (2008) Norepinephrine controls both torpor initiation and emergence via distinct mechanisms in the mouse. PLoS One 3:e4038. https://doi.org/10.1371/journal.pone.0004038

103. Talaei F, Bouma HR, Van der Graaf AC, Strijkstra AM, Schmidt M, Henning RH (2011) Serotonin and dopamine protect from hypothermia/rewarming damage through the $\mathrm{CBS} / \mathrm{H} 2 \mathrm{~S}$ pathway. PLoS One 6:e22568. https://doi.org/10.1371/journal.pone. 0022568

104. Talaei F, Hylkema MN, Bouma HR, Boerema AS, Strijkstra AM, Henning RH, Schmidt M (2011) Reversible remodeling of lung tissue during hibernation in the Syrian hamster. J Exp Biol 214: 1276-1282. https://doi.org/10.1242/jeb.052704

105. Talaei F, van Praag VM, Henning RH (2013) Hydrogen sulfide restores a normal morphological phenotype in Werner syndrome fibroblasts, attenuates oxidative damage and modulates mTOR pathway. Pharmacol Res 74:34-44. https://doi.org/10.1016/j. phrs.2013.04.011

106. Toien O, Blake J, Edgar DM, Grahn DA, Heller HC, Barnes BM (2011) Hibernation in black bears: independence of metabolic suppression from body temperature. Science 331:906-909. https://doi.org/10.1126/science.1199435

107. Trachsel L, Edgar DM, Heller HC (1991) Are ground squirrels sleep deprived during hibernation? Am J Phys 260:R1123-R1129. https://doi.org/10.1152/ajpregu.1991.260.6.R1123

108. Turgut O, Tandogan I, Karapinar H, Aydin G (2011) Preconditioning, postconditioning, stunning and hibernation: towards an integrated insight into the mechanisms of hypoperfusion/reperfusion. Int J Cardiol 146:442-443. https://doi.org/10. 1016/j.ijcard.2010.10.112

109. Tyagi A, Cohen M (2013) Oxygen consumption changes with yoga practices: a systematic review. J Evid-Based Complement Altern Med 18:290-308

110. van Breukelen F, Martin SL (2002) Reversible depression of transcription during hibernation. J Comp Physiol B 172:355-361. https://doi.org/10.1007/s00360-002-0256-1

111. Vyazovskiy VV, Borbely AA, Tobler I (2002) Interhemispheric sleep EEG asymmetry in the rat is enhanced by sleep deprivation. $J$ Neurophysiol 88:2280-2286. https://doi.org/10.1152/jn.00304.2002

112. Vyazovskiy VV, Welker E, Fritschy JM, Tobler I (2004) Regional pattern of metabolic activation is reflected in the sleep EEG after sleep deprivation combined with unilateral whisker stimulation in mice. Eur J Neurosci 20:1363-1370. https://doi.org/10.1111/j. 1460-9568.2004.03583.x

113. Webb CL, Milsom WK (2017) Effects of low temperature on breathing pattern and ventilatory responses during hibernation in the golden-mantled ground squirrel. J Comp Physiol B 187:793802. https://doi.org/10.1007/s00360-017-1079-4

114. Welinder KG, Hansen R, Overgaard MT, Brohus M, Sonderkaer M, von Bergen M, Rolle-Kampczyk U, Otto W, Lindahl TL, Arinell K, Evans AL, Swenson JE, Revsbech IG, Frobert O (2016) Biochemical foundations of health and energy conservation in hibernating free-ranging subadult brown bear Ursus arctos. J Biol Chem 291:22509-22523. https://doi.org/10.1074/jbc. M116.742916

115. Weltzin MM, Zhao HW, Drew KL, Bucci DJ (2006) Arousal from hibernation alters contextual learning and memory. Behav Brain Res 167:128-133. https://doi.org/10.1016/j.bbr.2005.08.021

116. Wilson WR, Hay MP (2011) Targeting hypoxia in cancer therapy. Nat Rev Cancer 11:393-410. https://doi.org/10.1038/nrc3064

117. Wu CW, Storey KB (2016) Life in the cold: links between mammalian hibernation and longevity. Biomol Concepts 7:41-52. https://doi.org/10.1515/bmc-2015-0032 